\title{
TERror, Trauma, Transitions: RePresenting ViOLEnCE IN SRI LANKaN
} LITERATURE

\author{
MARYSE JAYASURIYA
}

University of Texas at El Paso mjayasuriya@utep.edu

Received: 17-09-2015

Accepted: 01-02-2016

Sri Lankan literature in English, Sinhala, and Tamil has been shaped to a remarkable degree both by the brute fact of violence and by the varying ways in which Sri Lankans have responded to violence. The twenty-six year conflict between the Sri Lankan government and Tamil militant groups like the Liberation Tigers of Tamil Eelam (LTTE) and the briefer, but still bloody, conflict between the government and the Janata Vimukthi Peramuna (People's Liberation Front: JVP) required a response from nearly every Sri Lankan writer, resident or diasporic, in each of Sri Lanka's three languages. Sri Lankan writers sought to understand the roots of the conflict, foster dialogue and reconciliation, and bear witness to terrorism and repression by all sides.

The military conflict in Sri Lanka ended in 2009, marking a milestone in the country's long-running ethnic conflict. During the war and its aftermath, much has been written about violence. This essay seeks to provide an overview of the literature written about war, violence and terrorism by Sri Lankan writers. While my focus will be on Anglophone writers, I will also consider some works written in Sinhala and Tamil, which are now available in English translations. Some key subjects have captured the attention of writers: the 1983 pogrom in which Tamil lives and property were destroyed in Colombo; the terrorist acts carried out by separatist groups such as the LTTE; the second JVP insurgency in the late 1980s and early 1990s; the 
aftermath of the military conflict during which attacks were carried out against journalists and activists.

\section{Remembering Atrocity: The Burning of the Jaffna Public Library and the 1983 Ethnic Pogroms}

There are two moments to which writers go back over and over again because they signify the reasons for the start of the ethnic conflict, a rending of one type of nationalism and the inauguration of another. The first is the burning of the Jaffna Public Library by the police in 1981. The library was a centre of Tamil culture and learning, containing one of the biggest collections of writings in Tamil as well as priceless, irreplaceable ancient manuscripts. The burning of the building and the tomes inside represented to Sri Lankan Tamils an attack on their very culture and identity. The poet Cheran [Rudhramoorthy], son of the great Sri Lankan Tamil poet Mahakavi, writes about this in his poem "The Second Sunrise" (as translated from the Tamil by Chelva Kanaganayakam): "What happened?/ My town was burned;/ my people became faceless;/ in my land, my air,/ in everything,/ the stamp of outsiders" (Cheran, 2011: 7; 1.10-15). The poet is outraged and rallies fellow Tamils to fight: "From the ashen streets, arise and march" (Cheran, 2011: 7; 1.22-23). M. A. Nuhman, another Tamil poet, writes of this event in the poem "Murder" (as translated from the Tamil by S. Pathmanathan) as the destruction not only of Tamil culture but also the beliefs and values, perhaps the very humanity, of the majority of the Sinhalese who profess to be Buddhist. The speaker dreams that the Buddha, who preached nonviolence, has been shot dead by the police "on the steps/ of the Jaffna library" (Nuhman in Selvadurai, 2014: 448; 1.7-8) since "Without killing him/ it was impossible/ to harm even a fly" (Nuhman in Selvadurai, 2014: 448; 1.16-18).

Deepika Bahri has referred to the Partition as "an enduring trauma, [...] a wound that has never quite healed" (Bahri, 2006: 222). The so-called riots of 1983 have played a similar role in Sri Lanka and have been emphasized in many literary works. For a long time the official narrative was that the atrocities of July 1983 were the random eruptions of anger by Sinhalese who were enraged by the killings of thirteen Sinhalese soldiers in the North by Tamil guerrillas. In fact, the destruction wrought on Tamil homes, businesses and lives was orchestrated by the 
government, which was apparent because the perpetrators had electoral lists that enabled them to target Tamils. July 1983 was a shock to the system for many who had previously not seen themselves as involved in any particular ethnic conflict. Jean Arasanayagam writes about this in her poetry collection Apocalypse '83. As a Burgher (the descendant of Dutch colonizers) married to a Tamil, she finds herself and her family under attack and her loyalties - as someone with a hybrid identity-questioned; she realizes that she has to choose a side. She also writes about the experience of living in a refugee camp following the riots. The death and destruction caused by the riots resulted in many Tamils going into exile and becoming refugees in other countries. Shyam Selvadurai writes about the shock and horror of "Black July" in the first-person through the journal of his young Tamil protagonist Arjie in the novel Funny Boy. Since the last chapter of the novel is in the form of a journal, the horror of the violent events is conveyed with much immediacy and power: "all the Tamil shops had been set on fire and the mobs were looting everything. The police and army just stood by, watching, and some of them even cheered the mobs and joined in the looting and burning" (Selvadurai, 1994: 284). Arjie and his family seek refuge with their Sinhalese neighbours while their house is burned down by the mobs. Later they learn that mobs had set fire to the car of Arjie's grandparents with the elderly couple still inside. Arjie's family, like Sri Lankan Tamils all over the country, feel betrayed and make the decision to go to Canada as refugees. As Arjie writes in his diary, "I long to be out of this country. I don't feel at home in Sri Lanka any longer, will never feel safe again" (Selvadurai, 1994: 296).

Decades later, Karen Roberts in her novel July, V.V. Ganeshananthan in her novel Love Marriage, and Nayomi Munaweera in her novel Island of a Thousand Mirrors describe the tragic events of July 1983. Yalini, the protagonist in Love Marriage, is actually born in the United States while the anti-Tamil pogroms are happening in Sri Lanka: "Black July: more than two decades later, I think that almost every Sri Lankan Tamil knows what it means. I was born, and halfway across the world, Tamil people died, betrayed by their own country, which did nothing to save them" (Ganeshananthan, 2008: 18). Yalini's father watches the news from Colombo on television, sees that "people were being killed for their Tamilness" (18) and realizes "that he had left Sri Lanka totally and absolutely" (Ganeshananthan, 2008: 19). Munaweera, in her novel, writes of the far-reaching impact of July 1983: "Arteries, streams, and then rivers of Tamils flow out of the city. Behind them they leave: looted, soot-blackened houses, the unburied or unburnt 
bodies of loved ones, ancestral wealth, lost children, Belonging and Nationalism. It is a list that stays bitter on the tongue, giving birth to fantasies of Retribution, Partition, and Secession. [...] the events of that July will make them the most militant and determined of separatists" (Munaweera, 2012: 89). Both Roberts and Munaweera describe the violence of July 1983 and the resulting rending of the national fabric through the conceit of tragic romantic relationships between characters on opposite sides of the ethnic divide.

\section{Tracing Terror: The JVP, the LTTE, and the State}

The atrocities that helped to inaugurate Sri Lanka's conflicts were reenacted in various forms throughout the war between the government and the LTTE and the second JVP insurrection. In particular, attacks on civilians by government forces (military and paramilitary), the JVP, and the LTTE shocked the conscience of many Sri Lankan writers. The suicide bombings carried about by the LTTE in the 1990s and early 2000s became particularly visible on the international stage. Literary works focused on the violence in the North and the East between separatist groups - particularly the LTTE — and the Sri Lankan military during the various phases of the war.

In certain literary works that do not have the ethnic conflict as a primary focus, violence nonetheless pervades the lives of characters. For example, in Shehan Karunatilaka's awardwinning novel Chinaman: The Legend of Pradeep Mathew, the focus is on a cricket prodigy who has disappeared from public view and a journalist's attempt years later to find out what happened to him. We learn of how the violence of July 1983 affected Mathew, a Tamil, and the novel is punctuated by the war in the North and the East as well as the suicide bombings carried out by the LTTE in Colombo. Karunatilaka builds into his novel on cricket a murky subplot that involves the protagonist, an aging sports journalist obsessed with Pradeep Mathew, who is summoned to a secret hideout by an ostensible leader of the LTTE, and major plot elements frequently hinge on the possibility that Mathew is being exploited by the LTTE, even as it becomes evident that the trauma of the 1983 anti-Tamil pogroms and the anti-Tamil racism that he has experienced since have clearly traumatized Mathew.

Some have tried to depict the conflict through the eyes of both factions, attempting to help readers comprehend the complexity of the conflict and explain the motivations of the 
opposing sides to each other. In Nihal de Silva's novel The Road from Elephant Pass, the protagonists, a Sinhalese soldier and a female LTTE cadre, are thrown together when the latter offers to be an informer about the whereabouts of LTTE leader Prabhakaran and the soldier is ordered to take her to army headquarters. During their journey, the LTTE cadre details the discrimination and oppression faced by the Tamils that necessitated the struggle for a separate state and the soldier describes the terrorist acts of the LTTE that called for action to quell the separatists. In Cheran's poem "A Letter to a Sinhala Friend" (as translated from the Tamil by Lakshmi Holmström), the speaker reminds his correspondent how she might initially have perceived him, a Tamil: "It will not take long/ for you/ and your friends/ to recover from the shock/ of meeting me, an ordinary man,/ from an unseen and distant land/ where, you had heard,/ we sow lead-shots from guns/ instead of seeds" (Cheran, 2012: 47; 1.1-9). He describes how he was moved by her singing a Sinhala song and how they, despite their different languages, were able to savour the beauty of falling flowers and the movements of a peacock. He urges her "Tell your people/ here too, flowers bloom/ grass grows/ birds fly" (Cheran, 2012: 49; 1.73-76). In both the novel and the poem, an attempt is made to bridge the gap between the Sinhalese and the Tamils by means of an emphasis on common humanity and shared experiences.

Writers explore the reasons why people might take up arms, resort to violence and carry out terrorist acts. The female suicide bomber seems to be a figure that is of particular fascination. As I have argued elsewhere, attempts at understanding why a woman would choose to inflict violence, death and destruction on others tend to be aligned with gendered reasons such as rape or the loss of a family member in addition to the woman's political engagement or commitment to a cause. In order to understand or empathize with a female suicide bomber, the tropes of victimhood and/or motherhood are usually used to humanize the individual. In Amila Weerasinghe's poem "Suicide Bomber," the female speaker addresses a Tamil woman who has killed herself and others in a suicide attack and imagines that she must have been driven to this violence because she was raped by people of the speaker's own ethnicity, the Sinhalese. ${ }^{1}$ In Nayomi Munaweera's Island of a Thousand Mirrors, Saraswati is a Tamil girl who is raped by Sinhalese soldiers. She struggles with the trauma of the violence enacted on her body: "In Amma's cloudy mirror, I catch a glimpse of a girl. I know she is me, only because there is no

\footnotetext{
${ }^{1}$ See Jayasuriya, 2013.
} 
one else in the room. She is big-eyed, bruised, with a wounded torn mouth" (Munaweera, 2012: 149). The once-ambitious student is now no longer able to go to school due to trauma and the fact that she has been raped precludes the possibility of marriage within her context. Her mother finally urges her to join the LTTE: "What will you do here? What man will take what the soldiers have spoilt? Who will give their son for your sister? If you don't go, you will ruin us all. [...] You must go. Show people that you are a good girl. If you don't go, no one will believe that you were taken by force" (Munaweera, 2012: 132). Saraswati is thus victimized twice, once due to her ethnicity and again due to her gender. With apparently no other option left to her, she joins the LTTE and ultimately undertakes a suicide mission, dressed as a pregnant woman with explosives wrapped around her belly. Right before she detonates the bomb, she thinks: "They will remember me. All of them. My portrait, miles high, will hang everywhere extolling my bravery, the new cadres will come to stand in front of it, inhale the scent of my jasmine garland, be inspired by my fearlessness and dedication. Amma and Appa will be proud. Luxshmi will be the sister of a martyr. I cannot give them more than this" (Munaweera, 2012: 203). An exception to this type of depiction of the female suicide bomber is Lal Medawattegedera's short story "The Last War," which describes the aftermath of a suicide bombing: the remains, now literal fragments, of a variety of people who were killed during the attack-including the eye of the female suicide bomber - have a discussion about what happened. The eye of the suicide bomber remains defiant, steadfastly maintaining that the reason for the destruction she caused was the oppression faced by the Tamil people in general at the hands of the Sinhalese and arguing that such destruction is necessary to bring attention to the plight of the Tamils.

Literary works have also highlighted the so-called "Reign of Terror" in the South, during the second JVP insurgency. From the late 1980s to the early 1990s, Marxist-leaning, universityeducated youth carried out an attempt to overturn the status quo, and the Sri Lankan state, along with paramilitary forces, attempted to quell the insurgents as well as anyone associated with them. Michael Ondaatje's novel Anil's Ghost is set in that era, and dwells on the "disappeared" and the trauma of abduction and murder on those left behind through characters like the artist Ananda, who takes to drink and attempts suicide following the disappearance of his wife. Ondaatje even includes the actual names of those who were disappeared along with the dates of their abductions and the variety of ways in which they were taken. The novel also highlights the ethics of external intervention, of the journalists and human rights monitors who enter and leave 
a conflict zone and make reports and judgments based on a paltry few weeks of investigation through debates between Anil, a forensic anthropologist working under the auspices of the United Nations, and two brothers - Sarath, an archaeologist, and Gamini, a doctor — who live in Sri Lanka. Sarath and Gamini urge Anil to be responsible and to provide necessary contextualization in her reports about the violence in Sri Lanka. The terror psychosis of those who have experienced violence and therefore do not resist the demands and orders of perpetrators is described in Carl Muller's Colombo, a work that is referred to as a novel by the author but is actually a hybrid of creative non-fiction and fiction. In one episode, a couple living in an exclusive Colombo neighbourhood hear the sound of gunshots outside their house at night but refuse to investigate or call the police. They say and do nothing since they are uncertain whether the perpetrators are JVP insurgents, agents of law enforcement or paramilitary groups, all of whom would retaliate against any who would report the crime.

Many writers focus on atrocity, condemning the culpability of those whom they might have initially supported or with whom they are associated. In Cheran's "A Poem That Should Never Have Been Written" (as translated from the Tamil by Lakshmi Holmström), the speaker looks upon brutalized bodies and castigates the perpetrators, who happen to be from the same ethnic group: "For this is not the work of our enemies/ but bears the imprint/ of our own people's murderous hands" (Cheran, 2012: 60; 1.46-48). In Buddhadasa Galappatty's poem “The Stealing of a Jeweled Lamp" (as translated from the Sinhala by Malini Govinnage), the speaker is asking JVP insurgents - whom she seems to have supported and still refers to as "comrades" - why they killed her husband for the "crime" of lighting a lamp during a time when the JVP had imposed a blackout. She declares that she had asked her husband to light the lamp only because their child was afraid of the dark, not as a challenge against the authority of the JVP: "Where is your justice?/ Why could you not find out/ the reason he broke your law/ before you put out the lamp of my life?" (Galappatty in Selvadurai, 2014: 459; 1.18-21). At a time when dissidents were often attacked or assassinated, these moves can be deemed courageous.

Other works describe the traumatic effects of living in a conflict zone, witnessing almost daily acts of violence and experiencing trauma and survivor's guilt. In her short story "Exodus," Arasanayagam writes of a two-year old girl who already knows what to do when there is an air raid: aerial attacks have become part of her normal diurnal routine and she has learned the art of 
self-preservation. In Sivaramani's poem “Oppressed by Nights of War" (as translated from the Tamil by Lakshmi Holmström), the poet describes the impact of violence on the young: "Oppressed/ by nights of war/ our children/ become adults" (Sivaramani in Selvadurai, 2014: 473; 1.1-4). Reflecting the violence they see all around them, the children "pluck away/ the wings of dragonflies/ they shoulder sticks for guns/ their friends become their foes" (Sivaramani in Selvadurai, 2014: 474; 1.24-27). Kamala Wijeratne in the poem "White Saree" writes about the way in which attending the funerals of young men who have been killed on suspicion of being members or sympathizers of the JVP has become a daily occurrence. It has become so frequent that the speaker feels there is no point in putting away her mourning attire.

Memorials to the victims of violence are also an important focus. Sometimes the emphasis is on figures in the public eye - particularly those who refused to align themselves to one side and criticized wrongdoing on both sides-who have been assassinated; remembering these figures is a means of memorializing the countless and nameless others who have been killed or disappeared. It is a way of "re-membering" a shattered society. There have been many poems written about the brutal murder of journalist and poet Richard de Zoysa, who was abducted from his home by paramilitary forces and whose body washed up on a beach days later. There has been a similar attempt to memorialize the assassination of human rights activist and university professor Dr. Rajani Thiranagama, who criticized and wrote against the actions of the Sri Lankan government and the IPKF (Indian Peace Keeping Force) but then also condemned the atrocities carried out by the LTTE and was killed as a dissident by the latter. In both cases, literary works have focused on grief at lost potential. ${ }^{2}$ Others who were less well-known have also been memorialized: Vinothini's poem "Krishanthy" (as translated from the Tamil by M.A. Nuhman) is an elegy for a young Tamil schoolgirl who was gang-raped and murdered by six Sri Lankan soldiers: "When she was born as a female child/ neither she, nor her mother, could have thought/ of such an end" (Vinothini in Selvadurai, 2014: 467; 1.6-8). Sumathy's poem entitled "To the Memory of the Three-wheeler Driver Purportedly Shot Dead by the LTTE for Being Familiar with the Police" is a reluctant tribute by the speaker to an ordinary person, a cab driver, whose murder inconveniently threatens to disturb a ceasefire and is thus generally ignored.

\footnotetext{
${ }^{2}$ For an extended discussion of the importance of poetry in memorializing figures like Thiranagama and De Zoysa, see Jayasuriya, 2012. For more on Sri Lankan Anglophone literature and its contested status, see Qadri Ismail, Abiding by Sri Lanka and Minoli Salgado, Writing Sri Lanka.
} 
Sometimes the people who have been killed are remembered by means of the particular ways in which the destruction took place, such as the bombings of the Temple of the Tooth in Kandy in 1998 and the Colombo airport in 2001. Punyakante Wijenaike's novella An Enemy Within focuses on the bombing of the Central Bank in January 1996, and the different types of people - particularly civilians from different ethnicities — who were killed. The shifting narrative perspective enables Wijenaike to examine the trauma of the survivors and the victims' loved ones as well as the probable reasons for the suicide bomber who undertook the mission-the murder of his young son at the hands of the Sri Lankan army; he too is a victim. Raghu, the imagined suicide bomber in the novella, "did not allow himself to feel for those unknown, unarmed civilians" (Wijenaike, 1998: 18) who will die when he drives his lorry packed with explosives into the Central Bank building. "A smile twisted his mouth for a second to think that they, the Tigers, had caused such caution in Colombo. After today, there would come up more barricades, more fear. The army may have conquered Jaffna but Colombo was cowering in fear. A tooth for a tooth" (Wijenaike, 1998: 19).

Attention has also been given to the moral dilemmas faced by willing and unwitting participants of the conflict, both combatants and civilians. In Arasanayagam's short story "I am an Innocent Man," Das, a Tamil schoolteacher, feels guilty about his determination not to take sides - neither joining the militants nor cooperating with government forces trying to defeat the militants - and realizes that the very act of witnessing makes him complicit in the violence. In Neil Fernandopulle's short story "The Left-Behind," the widow of a soldier, even as she mourns the loss of a beloved husband, wonders uneasily about what he might have done-looting, raping-during his time in the North. In S. Vilvaratnam's poem "The Worship-Scar" (as translated from the Tamil by A.J. Canagaratna), the speaker asks about the scar on the forehead of a Muslim friend's father and is told that it is a "worship-scar"-_calling for Allah/ he had bowed until/ his native soil had scarred his bowed forehead" (Vilvaratnam in Selvadurai, 2014: $478 ; 1.8-10)$. The speaker is overwhelmed with guilt because he has participated in the expulsion of thousands of Muslims from their "native soil" in the North, an act of ethnic cleansing carried out by the LTTE in 1990: "Their worship-scars seared/ the guilt-stricken scar of my conscience/ [...] When, but when, will my scar disappear?/ When will my crime/ violating the beauty of the 
soil/ that is etched on their foreheads/ be expiated?" (Vilvaratnam in Selvadurai, 2014: 479; 1.1624).

Some writers have connected what has happened in Sri Lanka to violence taking place in other parts of the world at other times. Anne Ranasinghe has drawn parallels between the need to remember what happened in the Holocaust and what has happened in Sri Lanka in order to prevent such violence erupting again in poems such as "July 1983." At a point when terrorist violence has become a global concern, Aparna Halpé, in her poem "Of this November, Mumbai" connects what happened during the terrorist attack in Mumbhai in 2008 with the bombings that have occurred over the years in Colombo. Making these connections can perhaps make the local global and preclude the possibility of sensationalizing particular places as inherent sites of violence.

\section{The Murder of Civil Society: Recent Literary Responses to Violence Against Journalists and Dissidents}

Following the end of the military conflict, writers have focused on the killing of activists and journalists. The murder, in broad daylight, of Lasantha Wickrematunga-editor of The Sunday Leader and fierce critic of the government-has been marked in Vivimarie VanderPoorten's poem "Death at Noon." There have also been critiques of the government, the lack of genuine attempts at reconciliation and increasing militarization. The ongoing trauma of people displaced by violence and confined to camps as "IDPs" are also described. The ordeal of a country coming to terms with nearly three decades of war and violence and finding ways to cope are highlighted in Romesh Gunesekera's Noon Tide Toll and Lal Medawattegedera's Playing Pillow Politics at MGK.

In Gunesekera's novel, the protagonist, Vasantha, is the driver of a van for hire and he plies his vehicle up and down the country. In the first section of the novel, he takes clientsranging from tourists eager to see locations exoticized by the war and diasporics attempting to find their roots to representatives of foreign NGOs and international entrepreneurs interested in investing in the country - to the North, while the second section focuses on his travels around Galle and other areas in the south of the country. In his travels to the North, Vasantha encounters former combatants - people who were in the Sri Lankan military or members of militant groups 
such as the LTTE - who are attempting to reconcile themselves to the so-called peace. Many of them have been left scarred-emotionally and physically-by acts of violence they have perpetrated or witnessed. For example, Dilshan, a former soldier who is now a guide for tourists coming to the North, tells Vasantha about how he had to execute a female Tiger cadre who was suckling her baby; now he cannot look at his own mother without seeing the face of the woman he killed (Gunesekera, 2014: 21-22). Vasantha also meets Miss Saraswati, the assistant manager of the Spice Garden Inn in Kilinochchi, who believes that "it is better not to ask about the past" (Gunesekera, 2014: 102). Though she is determined to conceal her past and tries to keep areas of herself "cordoned off" (Gunesekera, 2014: 104), she is barely able to suppress feelings of loss or guilt; Vasantha observes her methodical and unflinching killing of rodents, sees her callused and discoloured trigger finger and her scarred neck, and suspects that she might have been a member of the Tigers. Other soldiers that Vasantha encounters "want to go back to the job. To have something to do, you know. [...] Rest and recuperation is not what they want" (Gunesekera, 2014: 132). As Vasantha observes, "The war was over. But you could say it was an encounter with the war within: guilt, which I am beginning to see riddles everything" (Gunesekera, 2014: 27). Along with the efforts of entrepreneurs to take advantage of the post-war situation and embark on money-making endeavors, there are also attempts to bring perpetrators of war crimes to justice. The question that the van driver wrestles with is "After all, people lose control, don't they, in times of war? The whole business is insane anyway, killing and maiming like there is no tomorrow. How can you shoot someone in the head and call it duty? How can anyone be normal after that?" (Gunesekera, 2014: 58). The issue at hand seems to be whether to allow witting or unwitting participants in violence to forget the past, reinvent themselves and live their lives, or to remember past atrocities in order to prevent their recurrence.

If Gunesekera's novel deals with discrete individuals' experiences and the memories and guilt that accompany them, Medawattegedera's highly-experimental novel attempts to probe the psyche of the nation in the post-war period. In Playing Pillow Politics at MGK, a young boy with disabilities named Deshan recounts the stories of a squatter community living on an isolated mountain called Maha Geeni Kanda (the "MGK" of the title) whose struggles and victories are, counterintuitively, parallel to those of Sri Lankans in general. Using fantasy and dark humour, Medawattegedera critiques the violence in what is supposedly a post-war Sri Lanka and the 
manipulations, exploitations, corruption, election fraud, surveillance, intimidation, silencing of opposition, thuggery and politically-motivated murders that have become endemic in the country. One of the main figures in the novel is Natami, who realizes that he can "read pillows" and discover the thoughts and ideas of the individuals whose heads rested on those pillows - thus literally making pillows talk. When news of Natami's unusual talent spreads to people beyond the mountain, he is pressured to focus his skill on reading the pillows of enemies of the government. He sees a pattern-anyone who is critical of the government ends up dead, beginning with the killing of the man he calls "Baba"- the editor of "The Pure Truth" newspaper (undoubtedly a reference to the murder of Lasantha Wickrematunga), who "roused Natami's sleeping political animal. During their long chat in Natami's hut, Baba lectured him on how intelligence could be used to undermine political authority. Baba showed him the power of political dialogue, the power of the written word, the power of resistive narration" (Medawattegedera, 2013: 351). After Baba's murder, Natami decides to seek revenge by "reading pillows" in such a way that he can get thugs, masterminds behind politically-motivated killings, and hired assassins themselves killed - by suggesting that they are on the verge of betraying the powers that be who have employed them. The escalation of these killings means, as Natami fully realizes, he himself has blood on his hands even if he tries to rationalize that those he gets killed deserve to die. ${ }^{3}$

Indeed, what ties together the many literary representations of and protests against violence in contemporary Sri Lankan literature is the way that so many texts expose complicity in violence. Some works point toward the complicity in violence of elites within the community that the writer does not belong to, some point towards the complicity of the author's own community, some point towards both, and some analyze the complicity of the international community. Many of these texts also seek to witness, acknowledge, and mourn the effects of violence, and many also seek to imagine a way beyond the impasses that the authors see at the time of writing. Despite hopeful signals in the news recently about Sri Lanka that impunity may be challenged and that reconciliation may be pursued with increasing vigor, the aspirations toward a just and lasting peace that so many of these texts express remain to be realized. Six years after the end of the military conflict, with so many uncertainties still hanging over the

\footnotetext{
${ }^{3}$ For a fuller discussion of Gunasekera and Medawattegedera, see Jayasuriya, 2015. 
nation, imagining a path toward peace and reconciliation remains essential. The task that Sri Lanka's writers of fiction and poetry have taken on in recording and responding to violence continues.

\section{WORKS CITED}

Arasanayagam, Jean (2003). Apocalypse '83, Colombo, Sri Lanka: International Centre for Ethnic Studies.

Arasanayagam, Jean (2002). “Exodus.” The Dividing Line, New Delhi: Indialog: 123-40.

Arasanayagam, Jean (1995). "I Am an Innocent Man.” All Is Burning, New Delhi: Penguin: $22-42$.

BAHRI, DEEPIKA (2006). "Telling Tales: Women and the Trauma of Partition in Sidhwa's Cracking India." Interventions: International Journal of Postcolonial Studies 1:2, 217 234 http://dx.doi.org/10.1080/13698019900510321 Accessed September 5, 2015.

CherAn (2012). “A Letter to a Sinhala Friend." A Second Sunrise. Ed. and Trans. Lakshmi Holmström and Sascha Ebeling. New Delhi: Navayana: 47-49.

ChERAN (2012). “A Poem That Should Never Have Been Written.” A Second Sunrise. Ed. and Trans. Lakshmi Holmström and Sascha Ebeling. New Delhi: Navayana: 59-61.

Cheran (2011). "The Second Sunrise." You Cannot Turn Away. Ed. and Trans. Chelva Kanaganayakam. Ontario: TSAR: 7.

De Mel, Neloufer (2001). Women and the Nation's Narrative: Gender and Nationalism in Twentieth-Century Sri Lanka. Colombo, Sri Lanka: Social Scientists' Association; Lanham, MD: Rowman and Littlefield.

De SiLva, Nihal (2003). The Road from Elephant Pass. Colombo, Sri Lanka: Vijitha Yapa.

FERNANDOPUlLE, NeIL (2000). "The Left-Behind." Shrapnel. Nugegoda, Sri Lanka: Sarasavi. 52-61.

Ganeshananthan, V.V. (2008). Love Marriage. New York: Random House.

GuneSEKerA, Romesh (2014). Noontide Toll. New Delhi: Penguin India.

Halpé, Aparna (2013). "Of this November, Mumbai.” Precarious: Poems. Colombo, Sri Lanka: Bay Owl: 20-24. 
ISMAIL, QADRI (2005). Abiding by Sri Lanka: On Peace, Place, and Postcoloniality. Minneapolis: University of Minnesota Press.

JAYASURIYA, MARYSE (2015). “Amnesia, Hallucinations and Fantasy: Narrating Sri Lanka's Post-War Conflict in Romesh Gunesekera's Noontide Toll and Lal Medawattegedera's Playing Pillow Politics at the MGK." Phoenix XII, 89-100.

JAYASURIYA, MARYSE (2013). "Exploding Myths: Representing the Female Suicide Bomber in the Sri Lankan Context in Literature and Film." Journal of Postcolonial Cultures and Societies 4:1, 233-257.

JAYASURIYA, MARYSE (2012). Terror and Reconciliation: Sri Lankan Anglophone Literature, 1983-2009. Lanham: Lexington Books.

Karunatilaka, Shehan (2011). Chinaman: The Legend of Pradeep Mathew. New Delhi: Random House India.

Medawattegedera, Lal (2013). Playing Pillow Politics at MGK. Colombo: Akna.

Medawattegedera, Lal (2008). "The Last War." Can You Hear Me Running. Colombo, Sri Lanka: Zeus: 78-83.

Muller, CARl (1995). Colombo: A Novel. New Delhi: Penguin Books India.

Munaweera, NAyOMI (2012). Island of a Thousand Mirrors. Colomob, Sri Lanka: Perera Hussein.

Nuhman, M.A. (2014). "Murder.” Many Roads through Paradise: An Anthology of Sri Lankan Literature. Ed. Shyam Selvadurai. London: Penguin: 448-49.

OndaAtJe, Michael (2000). Anil's Ghost. New York: Knopf.

Ranasinghe, Anne (1991). "July 1983." At What Dark Point. Orugodawatte, Sri Lanka: English Writers' Cooperative of Sri Lanka: 171.

ROBERTS, KAREN (2001). July. London: Phoenix.

Salgado, Minoli (2007). Writing Sri Lanka: Literature, Resistance, and the Politics of Place. London: Routledge.

Selvadurai, Shyam (1994). Funny Boy. San Diego: Harcourt Brace.

Sumathy, Sivamohan (2008). "To the Memory of the Three-Wheeler Driver Purportedly Shot Dead by the LTTE for Being Familiar with the Police." Like Myth and Mother: A Political Autobiography in Poetry and Prose. Colombo, Sri Lanka: Sirahununi: 44-49. 
Vanderpoorten, Vivimarie (2010). "Death at Noon." Stitch Your Eyelids Shut. Colombo, Sri Lanka: Akna: 38-39.

Vilvaratnam, S. (2014). "The Worship-Scar." Many Roads through Paradise: An Anthology of Sri Lankan Literature. Ed. Shyam Selvadurai. London: Penguin: 478-79.

WeERASINGHE, AMILA (2001). "Suicide Bomber." Anne Ranasinghe, ed. Channels: A Compendium of Creative Writing 1989-2001. Colombo, Sri Lanka: English Writers' Cooperative of Sri Lanka: 63.

Wijenaike, Punyakante (1998). An Enemy Within. Colombo, Sri Lanka: Sarvodaya Vishva Lekha.

Wijeratne, Kamala (1994). "White Saree." White Saree and Other Poems. Alawatugoda, Sri Lanka: Malinda: 7-8.

MARYSE JAYASURIYA is Associate Professor in the Department of English at the University of Texas at El Paso. She received her Ph.D. from Purdue University. She is the author of Terror and Reconciliation: Sri Lankan Anglophone Literature, 1983-2009 (Lexington, 2012), which explores the English language literature that has emerged from Sri Lanka's quarter-century long ethnic conflict. She has published articles on South Asian and Asian-American literature in such venues as South Asian Review, Journeys, Margins, and The Journal of Postcolonial Cultures and Societies. She co-edited a Special Issue of South Asian Review (33.3) entitled Sri Lankan Anglophone Literature. 